\title{
Coupling of Acetylide Ligands on an Electron-Rich Tetraruthenium Diphosphido Framework: Synthesis, Structure, and Reactivity Studies of $R u_{4}(C O)_{9}\left(\mu-P P h_{2}\right)_{2}\left(C_{2} B u^{t}\right)_{2}$ and $R u_{4}(C O)_{8}\left(\mu-P P h_{2}\right)_{2}\left(C_{4} B u^{t}{ }_{2}\right)$
}

\author{
Yun Chi, ${ }^{* \dagger}+$ Arthur J . Carty, ${ }^{*}, \neq$ Peter Blenkiron, $\neq$ Esther Delgado, $\neq$ \\ Gary D. Enright, $\neq$ Weibin Wang,, Shie-Ming Peng, ${ }^{*, \S}$ and Gene-Hsiang Lee \\ Department of Chemistry, National Tsing Hua University, Hsinchu 30043, Taiwan, Steacie \\ Institute for Molecular Sciences, National Research Council of Canada, 100 Sussex Drive, \\ Ottawa, Ontario K1A 0R6, Canada, and Department of Chemistry, National Taiwan \\ University, Taipe 10764, Taiwan
}

Received J une 24, $1996^{\otimes}$

Summary: Thermolysis of $\mathrm{Ru}_{2}(\mathrm{CO})_{6}\left(\mu-\mathrm{PPh}_{2}\right)\left(\mathrm{C}_{2} \mathrm{Bu}^{\mathrm{t}}\right)(\mathbf{1})$ in toluene afforded $\mathrm{Ru}_{4}(\mathrm{CO})_{9}\left(\mu-\mathrm{PPh}_{2}\right)_{2}\left(\mathrm{C}_{2} \mathrm{Bu}^{\mathrm{t}}\right)_{2}$ (2) in which the acetylide ligands are coordinated to a novel 64-electron butterfly platform. Upon thermolysis, this complex underwent $\mathrm{C}-\mathrm{C}$ bond coupling to givethediyne complexes $\mathrm{Ru}_{4}(\mathrm{CO})_{8}\left(u-\mathrm{PPh}_{2}\right)_{2}\left(\mathrm{C}_{4} \mathrm{Bu}_{2}\right)(3)$ and $\mathrm{Ru}_{3}(\mathrm{CO})_{7}(u-$ $\left.\mathrm{PPh}_{2}\right)_{2}\left(\mathrm{C}_{4} \mathrm{Bu}_{2} \mathrm{t}_{2}\right)(\mathbf{C})$ through sequential $\mathrm{CO}$ elimination and fragmentation, respectively.

The coupling of terminal or functionalized metal acetylides via methodologies such as oxidative ${ }^{1}$ or Cadiot-Chodkiewicz ${ }^{2}$ coupling has been extensively exploited recently to generate polycarbon ligand complexes and new molecular materials possessing extended carbon unsaturation. ${ }^{3}$ In principle, it should be possible to effect head-to-head or tail-to-tail linkage of acetylides or polyacetylides coordinated in a multisite fashion on a binuclear or cluster framework to synthesize new multimetallic polycarbon complexes in which the full potential of $\sigma$ - and $\pi$-electrons of the alkynyl fragments are used in bonding. This strategy has as yet been little exploited in organometallic chemistry. ${ }^{4}$ In this communication, we describe the stereospecific high-yield head-to-head intermolecular coupling of $\mu-\eta^{1}$ : $\eta^{2}$-alkynyl groups in $\mathrm{Ru}_{2}(\mathrm{CO})_{6}\left(\mu-\mathrm{PPh}_{2}\right)\left(\mathrm{C} \equiv \mathrm{CBu}^{\mathrm{t}}\right)^{5}(\mathbf{1})$ molecules to produce an eight-el ectron-donor butadiyne ligand on an $\mathrm{Ru}_{4}$ framework. Although the cleavage of diynes by transition-metal clusters has been reported, ${ }^{6}$

\footnotetext{
+ National Tsing Hua University.

₹ National Research Council of Canada.

$\S$ National Taiwan University.

${ }^{\otimes}$ Abstract published in AdvanceACS Abstracts, November 1, 1996.

(1) (a) Hay, A. S. J . Org. Chem. 1962, 27, 3320. (b) Zhou, Y.; Seyler, J. W.; Weng, W.; Arif, A. M.; Gladysz, J. A. J . Am. Chem. Soc. 1993, 115, 8509. (c) Brady, M.; Weng, W.; Gladysz, J . A. J . Chem. Soc., Chem. Commun. 1994, 2655. (d) Yuan, Z.; Stringer, G.; J obe, I. R.; Kreller, D.; Scott, K.; Koch, L.; Taylor, N.J .; Marder, T. B. J . Organomet. Chem.
} 1993, 452, 115 .

(2) (a) Chodkiewicz, W.; Cadiot, P. C. R. Hebd. Seances Acad. Sci. 1955, 241, 1055. (b) Worth, G. H.; Robinson, B. H.; Simpson, J . Organometallics 1992, 11, 501. (c) Bartik, T.; Bartik, B.; Brady, M.; Dembinski, R.; Gladysz, J. A. Angew. Chem., Int. Ed. Engl. 1996, 35, 414.

(3) Lagow, R. J .; Kampa, J J J .; Wei, H.-C.; Battle, S. L.; Genge, J . W.; Laude, D. A.; Harper, C. J .; Bau, R.; Stevens, R. C.; Haw, J. F.; Munson, E. Science 1995, 267, 362.

(4) (a) Akita, M.; Sugimoto, S.; Terada, M.; Moro-oka, Y. J . Organomet. Chem. 1993, 447, 103. (b) Crescenzi, R.; Sterzo, C. L. Organometallics 1992, 11, 4301. (c) Hwang, D.-K.; Lin, P.-J .; Chi, Y.; Peng, S.-M.; Lee, G.-H. J . Chem. Soc., Dalton Trans. 1991, 2161. (d) Wu, C.-H.; Chi, Y.; Peng, S.-M.; Lee, G.-H. J . Chem. Soc., Dalton Trans. 1990, 3025. (e) Matsuzaka, H.; Hirayama, Y.; Nishio, M.; Mizobe, Y.; Hidai, M. Organometallics 1993, 12, 36. (f) J eannin, S.; J eannin, Y.; Robert, F.; Rosenberger, C. Inorg. Chem. 1994, 33, 243. (g) Heeres, H. J .; Nijhoff, J .; Teuben, J . H.; Rogers, R. D. Organometallics 1993, 12, 2609.

(5) Cherkas, A. A.; Randall, L. H.; MacLaughlin, S. A.; Mott, G. N.;

Taylor, N. J . Carty, A. J . Organometallics 1988, 7, 969. the formation of diynes from intermolecular coupling of acetylides is, to our knowledge, rare. $^{7}$

Thermolysis of $\mathbf{1}$ in toluene solution at reflux for $4 \mathrm{~h}$ afforded a 1:1 mixture of diacetylide complex $\mathrm{Ru}_{4}(\mathrm{CO})_{9}(u$ $\left.\mathrm{PPh}_{2}\right)_{2}\left(\mathrm{C}_{2} \mathrm{Bu}^{\mathrm{t}}\right)_{2}(2)$ and diyne metal complex $\mathrm{Ru}_{4}(\mathrm{CO})_{8}(u-$ $\left.\mathrm{PPh}_{2}\right)_{2}\left(\mathrm{C}_{4} \mathrm{Bu}_{2} \mathrm{t}_{2}\right.$ (3) as a mixture of red crystalline materials in $57 \%$ yield after recrystallization from $\mathrm{CH}_{2-}$ $\mathrm{Cl}_{2}$ and methanol at room temperature. Attempts to separate these cluster complexes by chromatography proved fruitless because of the similar $R_{f}$ values and the rapid decomposition of $\mathbf{3}$ on contact with silica gel. However, thermolysis of the mixture in toluene for $1 \mathrm{~h}$ led to the isolation of $\mathbf{3}$ with $\geq 95 \%$ purity and in nearly quantitative yield. This suggested that complex $\mathbf{2}$ is an intermediate prior to the formation of 3. Accordingly, pure $\mathbf{2}$ was obtained by treatment of the mixture with carbon monoxide in toluene $\left(1 \mathrm{~atm}, 80^{\circ} \mathrm{C}\right)$ for $5 \mathrm{~min}$. Under such conditions, complex $\mathbf{3}$ present in the mixture was found to convert into triruthenium cluster $\mathrm{Ru}_{3}(\mathrm{CO})_{7}\left(\mu-\mathrm{PPh}_{2}\right)_{2}\left(\mathrm{C}_{4} \mathrm{Bu}_{2}^{\mathrm{t}}\right)(\mathbf{4})$ in $90 \%$ yield, leaving 2 intact. The clusters $\mathbf{2}$ and $\mathbf{4}$ can then be separated using chromatographic workup followed by recrystallization. These stepwise transformations can be summarized:

$$
\begin{aligned}
& 2 \mathrm{Ru}_{2}(\mathrm{CO})_{6}\left(\mu-\mathrm{PPh}_{2}\right)\left(\mathrm{C}_{2} \mathrm{Bu}^{\mathrm{t}}\right) \rightarrow \\
& \mathbf{1} \\
& \mathrm{Ru}_{4}(\mathrm{CO})_{9}\left(\mu-\mathrm{PPh}_{2}\right)_{2}\left(\mathrm{C}_{2} \mathrm{Bu}^{\mathrm{t}}\right)_{2} \rightarrow \\
& \mathbf{2} \\
& \mathrm{Ru}_{4}(\mathrm{CO})_{8}\left(\mu-\mathrm{PPh}_{2}\right)_{2}\left(\mathrm{C}_{4} \mathrm{Bu}_{2}^{\mathrm{t}}\right) \rightarrow \\
& \mathbf{3} \\
& \mathrm{Ru}_{3}(\mathrm{CO})_{8}\left(\mu-\mathrm{PPh}_{2}\right)_{2}\left(\mathrm{C}_{4} \mathrm{Bu}_{2}^{\mathrm{t}}\right)+\mathrm{Ru}_{3}(\mathrm{CO})_{12} \\
& \mathbf{4}
\end{aligned}
$$

The reaction sequences $\mathbf{2} \rightarrow \mathbf{3} \rightarrow \mathbf{4}$ were further verified by conversion of a pure sample of $\mathbf{2}$ in toluene and by treatment of a pure sample of $\mathbf{3}$ with CO under identical conditions.

Compounds 2-4 were initially characterized by spectral methods. ${ }^{8}$ Single-crystal X-ray diffraction studies

(6) (a) Deeming, A. J .; Felix, M. S. B.; Bates, P. A.; Hursthouse, M B. J . Chem. Soc., Chem. Commun. 1987, 461. (b) Deeming, A. J .; Felix M. S. B.; Nuel, D. Inorg. Chim. Acta 1993, 213, 3. (c) Maekawa, M.; Munakata, M.; Kuroda-Sowa, T.; Hachiya, K. I norg. Chim. Acta 1995, 233, 1. (d) Rosenthal, U.; Pulst, S.; Arndt, P.; Ohff, A.; Tillack, A.; Baumann, W.; Kempe, R.; Burlakov, V. V. Organometallics 1995, 14 2961.

(7) (a) Ustynyuk, N. A.; Vinogradova, V. N.; Korneva, V. N.; Kravtsov, D. N.; Andrianov, V. G.; Struchkov, Y. T. J . Organomet. Chem. 1984, 277, 285. (b) Bruce, M. I.; Zaitseva, N. N.; Skelton, B W.; White, A. H. J . Cluster Sci. 1996, 7, 109 and references therein. 


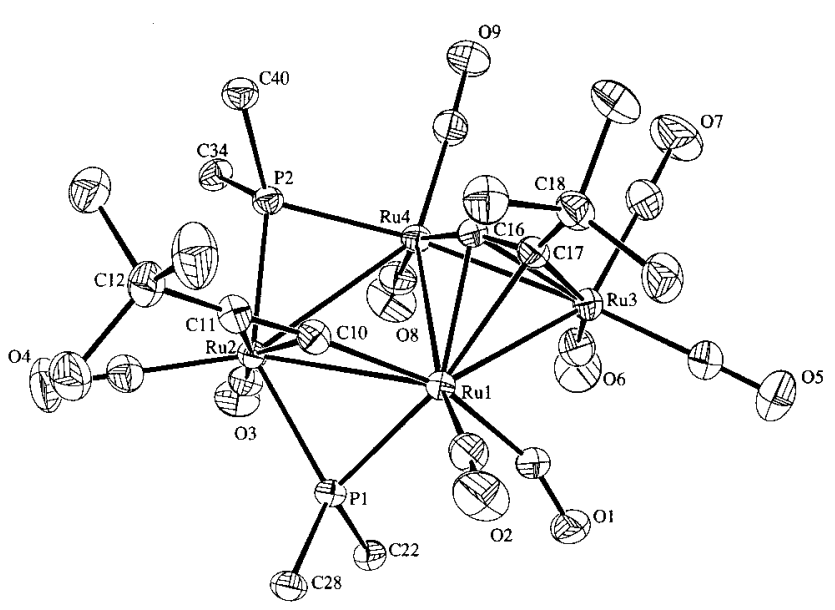

Figure 1. Molecular structure of $\mathbf{2}$ and the atomic numbering scheme. The phenyl groups of the phosphido ligands are omitted for clarity. Selected bond lengths $(\AA)$ : $\mathrm{Ru}(1)-\mathrm{Ru}(2)=3.0207(4), \mathrm{Ru}(1)-\mathrm{Ru}(3)=2.7815(4)$, Ru$(1)-\mathrm{Ru}(4)=3.0437(4), \mathrm{Ru}(2)-\mathrm{Ru}(4)=3.0974(4), \mathrm{Ru}(3)-$ $\mathrm{Ru}(4)=2.8575(4), \mathrm{Ru}(1)-\mathrm{P}(1)=2.366(1), \mathrm{Ru}(2)-\mathrm{P}(1)=$ 2.344(1), Ru(2)-P(2) = 2.358(1), Ru(4)-P(2) = 2.302(1), Ru$(1)-C(10)=2.052(4), R u(2)-C(10)=2.293(4), C(10)-C(11)$ $=1.209(6), \mathrm{Ru}(1)-\mathrm{C}(16)=2.222(4), \mathrm{Ru}(3)-\mathrm{C}(16)=2.205-$ (4), $\mathrm{Ru}(4)-\mathrm{C}(16)=1.968(4), \mathrm{Ru}(1)-\mathrm{C}(17)=2.324(4), \mathrm{Ru}-$ $(3)-C(17)=2.214(4), C(16)-C(17)=1.296(6)$.

on $\mathbf{2}$ and $\mathbf{3}$ were carried out to confirm their molecular structures. As indicated in Figure $1,{ }^{9}$ the cluster framework of $\mathbf{2}$ shows a flattened-butterfly geometry with the Ru-Ru distances adopting a pattern of two normal Ru-Ru bonds (2.7815(4)-2.8575(4) $\AA$ ) and three elongated Ru-Ru bonds (3.0207(4)-3.0974(4) $\AA$ ). This skeletal arrangement is similar to that of the $64 \mathrm{e}$, electron-rich cluster compounds $\mathrm{Ru}_{4}(\mathrm{CO})_{13}\left(\mu-\mathrm{PR}_{2}\right)_{2}(\mathrm{R}=$ $\left.\mathrm{Ph}, \mathrm{Et}, \mathrm{Cy}, \mathrm{Pr}^{\mathrm{i}}\right){ }^{10}$ In addition, the cluster contains two multisite-bound acetylide ligands. The acetylide C(16)$C(17)$, which possesses a $\mu_{3}-\eta^{2}$-bonding mode, ${ }^{11}$ lies on the $R u(1)-R u(3)-R u(4)$ triangle with its $\alpha$-carbon con-

(8) Spectral data for 2: MS (FAB, 102Ru), m/z $1192\left(M^{+}\right)$; IR $\left(\mathrm{C}_{6} \mathrm{H}_{14}\right)$ $v(\mathrm{CO}) 2068$ (vs), 2031 (vs), 2014 (s), 1999 (s), 1993 (m), 1962 (m), 1952 (m), 1936 (w) $\mathrm{cm}^{-1}$; ${ }^{1} \mathrm{H}$ NMR $\left(300 \mathrm{MHz} \mathrm{CDCl}_{3}\right) \delta 8.22(\mathrm{~m}, 2 \mathrm{H}), 7.96$ $(\mathrm{m}, 2 \mathrm{H}), 7.58-7.44(\mathrm{~m}, 6 \mathrm{H}), 7.30(\mathrm{~m}, 2 \mathrm{H}), 7.10-7.06(\mathrm{~m}, 6 \mathrm{H}), 6.58(\mathrm{~m}$ $2 \mathrm{H}), 1.53\left(\mathrm{~s}, 9 \mathrm{H}, \mathrm{Bu}^{\mathrm{t}}\right), 0.31\left(\mathrm{~s}, 9 \mathrm{H}, \mathrm{Bu}^{\mathrm{t}}\right) ;{ }^{31} \mathrm{P}$ NMR $\left(121.5 \mathrm{MHz}^{2} \mathrm{CDCl}_{3}\right)$ $\delta 138.3\left(\mathrm{~d}, J_{\mathrm{p}-\mathrm{p}}=177 \mathrm{~Hz}, 1 \mathrm{P}\right), 135.8\left(\mathrm{~d}, \mathrm{~J}_{\mathrm{p}-\mathrm{p}}=177 \mathrm{~Hz}, 1 \mathrm{P}\right)$. Anal. Calcd for $\mathrm{C}_{45} \mathrm{H}_{38} \mathrm{O}_{9} \mathrm{P}_{2} \mathrm{Ru}_{4}$ : C, 45.46; $\mathrm{H}, 3.22$. Found: $\mathrm{C}, 45.43 ; \mathrm{H}, 3.22$. Spectral data for 3: MS (FAB, 102Ru), $\mathrm{m} / \mathrm{z} 1164\left(\mathrm{M}^{+}\right)$; IR $\left(\mathrm{C}_{6} \mathrm{H}_{14}\right): v$ (CO), 2032 (vw), 2009 (vs), 1997 (m), 1971 (s), 1961 (w), $1949(\mathrm{~m}) \mathrm{cm}^{-1}$; ${ }_{1} \mathrm{H}$ NMR $\left(200 \mathrm{MHz}_{2} \mathrm{CDCl}_{3}\right) \delta 7.28-7.11(\mathrm{~m}, 16 \mathrm{H}), 7.01-6.93(\mathrm{~m}, 4 \mathrm{H})$, $1.63\left(\mathrm{~s}, 18 \mathrm{H}, 2 \mathrm{Bu}^{\mathrm{t}}\right)$; ${ }^{31 \mathrm{P} \mathrm{NMR}}\left(121.5 \mathrm{MHz}, \mathrm{CDCl}_{3}\right) \delta 194.8(\mathrm{~s}, 2 \mathrm{P})$. Anal. Calcd for $\mathrm{C}_{44} \mathrm{H}_{38} \mathrm{O}_{8} \mathrm{P}_{2} \mathrm{Ru}_{4}$ : C, 45.52, $\mathrm{H}$, 3.30. Found: C, 45.30; $\mathrm{H}, 3.17$. Spectral data for 4: MS (FAB, $\left.{ }^{102} \mathrm{Ru}\right), \mathrm{m} / \mathrm{z} 1034\left(\mathrm{M}^{+}\right)$; I $\mathrm{R}\left(\mathrm{C}_{6} \mathrm{H}_{14}\right) v$ (CO) 2056 (s), 2028 (s), 2013 (vs), 1993 (s), 1987 (m), 1973 (m), 1948 (w) $\mathrm{cm}^{-1}$; ${ }^{\mathrm{H}} \mathrm{NMR}\left(300 \mathrm{MHz}, \mathrm{CDCl}_{3}, 293 \mathrm{~K}\right) \delta 7.92-7.88(\mathrm{~m}, 4 \mathrm{H}), 7.72-$ $7.67(\mathrm{~m}, 4 \mathrm{H}), 7.42-7.40(\mathrm{~m}, 6 \mathrm{H}), 7.33-7.29(\mathrm{~m}, 6 \mathrm{H}), 1.13\left(\mathrm{~s}, 9 \mathrm{H}, \mathrm{Bu}^{\mathrm{t}}\right)$, $0.69\left(\mathrm{~s},{ }^{9} \mathrm{H}, \mathrm{Bu}^{\mathrm{t}}\right) ;{ }^{31} \mathrm{P} \mathrm{NMR}\left(121.5 \mathrm{MHz}^{\mathrm{C} C D C l}, 203 \mathrm{~K}\right) \delta 275.8(\mathrm{~d}, \mathrm{~J}-\mathrm{P}$ $=152 \mathrm{~Hz}, 1 \mathrm{P}), 188.3(\mathrm{~J}-\mathrm{p}=152 \mathrm{~Hz}, 1 \mathrm{P})$. Anal. Calcd for $\mathrm{C}_{43} \mathrm{H}_{38} \mathrm{O}_{7} \mathrm{P}_{2^{-}}$ $\mathrm{Ru}_{3}$ : C, 50.05; $\mathrm{H}, 3.71$. Found: $\mathrm{C}, 49.99, \mathrm{H}, 3.75$.

(9) Crystal data for 2: $\mathrm{C}_{45} \mathrm{H}_{38} \mathrm{O}_{9} \mathrm{P}_{2} \mathrm{Ru}_{4}, \mathrm{M}=1189.01$, monodinic, space group $P 21 / n, a=14.201(1) \AA, b=18.009(1) \AA, c=18.218(1) \AA$, $\beta=98.698(4)^{\circ}, \mathrm{V}=4605.6(3) \AA^{3}, \mathrm{Z}=4, \rho_{\text {calcd }}=1.715 \mathrm{~g} \mathrm{~cm}^{-3}, \mathrm{~F}(000)$ $=2344, \lambda\left(\mathrm{Cu} \mathrm{K}_{\alpha}\right)=1.541 \AA, T=298 \mathrm{~K}, \mu=11.79 \mathrm{~mm}^{-1}$. The intensities were measured on a Nonius CAD4 diffractometer on a crystal with dimensions $0.30 \times 0.25 \times 0.13 \mathrm{~mm}$. Of the 8742 unique reflections collected, 7427 reflections with I > 2.5 $\sigma(I)$ were used for the refinement. The structure was solved by using the NRCC-SDP-VAX package and refined to $\mathrm{R}_{\mathrm{F}}=0.032, \mathrm{R}_{\mathrm{w}}=0.044$, and GOF $=1.46$ for 98 atoms and 542 parameters, weighting scheme $\omega^{-1}=\sigma^{2}\left(\mathrm{~F}_{\mathrm{o}}\right)+0.0005 \mathrm{~F}_{0}{ }^{2}$, and highest $\Delta / \sigma$ ratio 0.14 . A difference map following convergence showed residual electron density within the range $-0.61 / 1.33 \mathrm{e} / \AA^{3}(\mathrm{~min} / \mathrm{max})$.

(10) (a) Hogarth, G.; Hadj-Bagheri, N.; Taylor, N . J .; Carty, A. J . J . Chem. Soc., Chem. Commun. 1988, 1570. (b) Corrigan, J . F.; Doherty, S.; Taylor, N. J .; Carty, A. J . J . Am. Chem. Soc. 1992, 114, 7557. (c) Corrigan, J . F.; Dinardo, M.; Doherty, S.; Hogarth, G.; Sun, Y.; Taylor, N. J .; Carty, A. J . Organometallics 1994, 13, 3572.

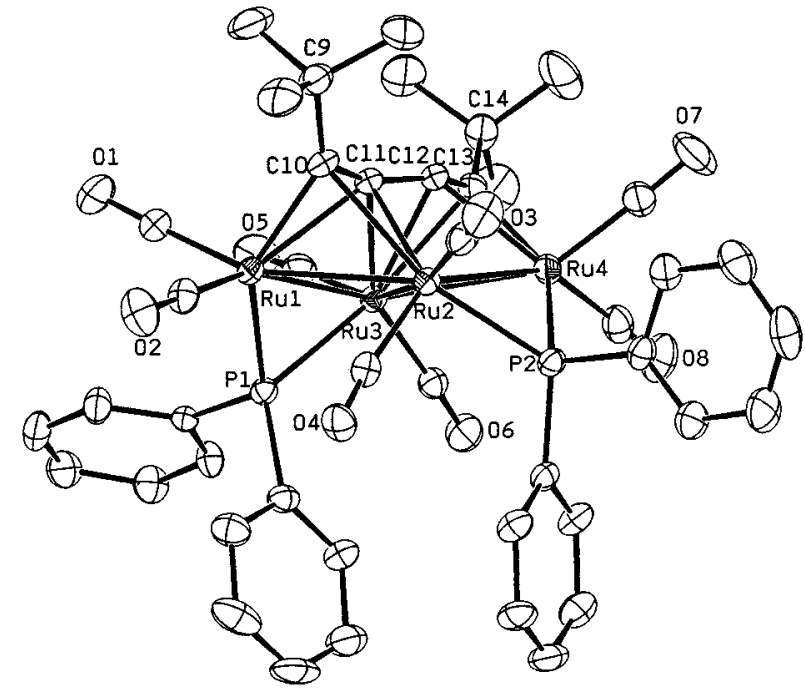

Figure 2. Molecular structure of $\mathbf{3}$ and the atomic numbering scheme. Selected bond lengths $(\AA)$ : Ru(1)-Ru$(2)=2.814(1), R u(1)-R u(3)=2.875(1), R u(2)-R u(3)=$ 2.924(1), $\mathrm{Ru}(2)-\mathrm{Ru}(4)=2.844(1), \mathrm{Ru}(3)-\mathrm{Ru}(4)=2.821-$ (1), $\mathrm{Ru}(1)-\mathrm{P}(1)=2.319(1), \mathrm{Ru}(3)-\mathrm{P}(1)=2.352(2), \mathrm{Ru}(2)-$ $\mathrm{P}(2)=2.331(1), \mathrm{Ru}(4)-\mathrm{P}(2)=2.313(2), \mathrm{Ru}(1)-\mathrm{C}(10)=$ 2.053(5), $\mathrm{Ru}(2)-\mathrm{C}(10)=2.430(5), \mathrm{Ru}(1)-\mathrm{C}(11)=2.361-$ (5), $\mathrm{Ru}(2)-\mathrm{C}(11)=2.183(5), \mathrm{Ru}(3)-\mathrm{C}(11)=2.363(5)$, Ru$(2) \cdots C(12)=2.700(5), R u(3)-C(12)=2.186(5), R u(4)-C(12)$ $=2.247(5), \mathrm{Ru}(3)-\mathrm{C}(13)=2.371(5), \mathrm{Ru}(4)-\mathrm{C}(13)=2.106-$ (5), $\mathrm{C}(10)-\mathrm{C}(11)=1.332(7), \mathrm{C}(11)-\mathrm{C}(12)=1.366(7)$, $\mathrm{C}(12)-\mathrm{C}(13)=1.321(7)$.

nected to the $\mathrm{Ru}(4)$ atom via a $\sigma$-bond and with the $\mathrm{C}-\mathrm{C}$ vector perpendicular to the $\mathrm{Ru}(1)-\mathrm{Ru}(3)$ bond. The other, $\mathrm{C}(10)-\mathrm{C}(11)$, which adopts the less common $\mu_{2^{-}}$ $\eta^{2}$-mode, ${ }^{12}$ resides on the $\mathrm{Ru}(1)-\mathrm{Ru}(2)$ bond and pushes the phosphido bridge away from the triangular plane defined by $R u(1), R u(2)$, and $R u(4)$ atoms. The lengths of the $-\mathrm{C} \equiv \mathrm{C}-$ bonds in the acetylideligands reflect the coordination mode $\mathrm{e}^{5,11,12}$ with the more highly coordinated $\mu_{3}-\eta^{2}$-bond $(\mathrm{C}(16)-\mathrm{C}(17)=1.296(6) \AA)$ being longer than the $\mu_{2}-\eta^{2}$-bond $(C(10)-C(11)=1.209(6) \AA)$. Interestingly, the acetylide ligands also align in a configuration with the sterically bulky tert-butyl substituents pointing away from each other.

The molecular structure of the diyne complex $\mathbf{3}$ is shown in Figure 2.13 The cluster, with 62 valence electrons, adopts a butterfly geometry similar to that of $\mathbf{2}$. The four peripheral Ru-Ru bonds span the narrow range $2.814(1)-2.875(1) \AA$ and are shorter than the hinge $\mathrm{Ru}(2)-\mathrm{Ru}(3)$ bond $(2.924(1) \AA)$. Although the basic cluster framework is retained, one phosphido ligand has migrated to the Ru-Ru edge parallel to the

(11) (a) Hwang, D.-K.; Chi, Y.; Peng, S.-M.; Lee, G.-H. Organome tallics 1990, 9, 2709. (b) Sappa, E.; Tiripicchio, A.; Braunstein, P. Chem. Rev. 1983, 83, 203.

(12) (a) Carty, A. J .; Taylor, N. J .; Smith, W. F. J . Chem. Soc., Chem. Commun. 1979, 750. (b) Carty, A. J .; MacLaughlin, S. A.; Wagner, J . V.; Taylor, N. J . Organometallics 1982, 1, 1013. (c) Cherkas, A. A.; Taylor, N. J .; Carty, A. J . J . Chem. Soc., Chem. Commun. 1990, 385.

(13) Crystal data for 3: $\mathrm{C}_{44} \mathrm{H}_{38} \mathrm{O}_{8} \mathrm{P}_{2} \mathrm{Ru}_{4}, \mathrm{M}=1161.00$, triclinic, space group $P \overline{1}, a=12.022(3) \dot{\AA}, b=12.768(4) \AA, c=16.218(3) \AA, \alpha=85.42$ $(2)^{\circ}, \beta=86.11(2)^{\circ}, \gamma=63.56(2)^{\circ}, \mathrm{V}=2220.6(10) \AA^{3}, \mathrm{Z}=2, \rho_{\text {calcd }}=$ $1.736 \mathrm{~g} \mathrm{~cm}^{-3}, \mathrm{~F}(000)=1133, \lambda(\mathrm{M} \circ \mathrm{K} \alpha)=0.7107 \AA, \mathrm{T}=298 \mathrm{~K}, u=$ $14.33 \mathrm{~cm}^{-1}$. The intensities were measured on a crystal with dimensions $0.20 \times 0.25 \times 0.25 \mathrm{~mm}$. Of the 7806 unique reflections collected, 5690 reflections with $\mathrm{I}>2 \sigma(\mathrm{I})$ were used for the refinement. The structure was refined to $R_{F}=0.029, R_{w}=0.030$, and $G O F=1.20$ for 96 atoms and 524 parameters, weighting scheme $\omega^{-1}=\sigma^{2}\left(\mathrm{~F}_{\mathrm{o}}\right)+0.0001$ $\mathrm{F}_{0}{ }^{2}$, and highest $\Delta / \sigma$ ratio 0.009 . A difference map following convergence showed residual electron density within the range $-0.36 / 0.34 \mathrm{e} / \AA^{3}$ (min/ $\max )$. 
second phosphido ligand, and the phosphido-bridged $\mathrm{Ru}-\mathrm{Ru}$ bonds (2.875(1) and 2.844(1) $\AA$ ) are noticeably shorter than those of $\mathbf{2}$, consistent with an increase of bond order through alleviation of excess el ectrons from the metal-metal antibonding orbital. ${ }^{14}$ The butadiyne ligand, generated from the end-to-end coupling of acetylide ligands, now acts as a $\mu_{4}$-bridge across the $\mathrm{Ru}_{4}$ surface. The diyne $\mathrm{C}_{4}$ backbone is slightly nonlinear with angles $C(10)-C(11)-C(12)=158.9(5)^{\circ}$ and $C(11)-$ $\mathrm{C}(12)-\mathrm{C}(13)=156.2(5)^{\circ}$. The $\mathrm{C}-\mathrm{C}$ bond lengths within this $C_{4}$ unit are consistent with the parameters observed for other coordinated diynes, ${ }^{15}$ where the net effect of coordination is to el ongate the outer formal triple bonds $(C(10)-C(11)=1.332(7) \AA$ and $C(12)-C(13)=1.321(7)$ $\AA$ in 3) and shorten the inner $C_{s p}-C_{s p}$ single bond $(C(11)-C(12)=1.366(7) \AA)$. In fact, $C(10)-C(11)$ and $C(12)-C(13)$ in $\mathbf{3}$ are both longer than the acetylenic triple bonds in $\mathbf{2}$ from which they are derived. It is of interest to note that the Ru(2)-C(12) bond (2.700(5) $\AA$ ) is significantly longer than the rest of the $\mathrm{Ru}-\mathrm{C}$ distances $(2.053(5)-2.430(5) \AA$ ), indicating the absence of direct bonding. However, if we ignore this nonbonding interaction, the cluster core skeleton can be considered to possess a $C_{2}$ axis passing through the center of the diyne ligand and the middle of the hinge $\mathrm{Ru}(2)-$ $\mathrm{Ru}(3)$ bond. In fact, the observation of only one ${ }^{1} \mathrm{H} N M R$ signal at $\delta 1.63$ due to the $\mathrm{Bu}^{\mathrm{t}}$ groups and one ${ }^{31 \mathrm{P}} \mathrm{NMR}$ signal at $\delta 194.8$ even at $190 \mathrm{~K}$ indicates the formation of such dynamic $\mathrm{C}_{2}$ symmetry in solution.

The isolation and characterization of complexes $\mathbf{2}$ and 3 provide an opportunity to explore the reactions taking place at the $\mathrm{Ru}_{2}$ metal centers. We propose that dimerization with $\mathrm{CO}$ loss leads to the formation of an intermediate (A) via a side-by-side and head-to-head alignment of $\mathbf{1}$ and the formation of two Ru-Ru interactions (Scheme 1). Upon further removal of a CO ligand the intermediate $\mathbf{A}$ would strengthen the bonding between each $\mathrm{Ru}_{2}\left(\mu-\mathrm{PPh}_{2}\right)\left(\mathrm{CCBu}^{\mathrm{t}}\right)$ unit through the simultaneous generation of a third Ru-Ru bond at the hinge position. Phosphido ligand migration, and formation of one $\mu_{3}-\eta^{2}$-acetylide ligand, eventually leads to the formation of $\mathbf{2}$. With loss of CO from $\mathbf{2}$ the acetylide ligands then undergo head-to-head coupling to afford the diyne ligand on cluster $\mathbf{3}$. This diyne ligand is considered as an eight-electron donor and is bonded to all four ruthenium atoms, but in an almost linear fashion, quite different from that observed in other diyne clusters such as $\mathrm{Ru}_{4}(\mathrm{CO})_{10}\left(\mu_{4}-\mathrm{PR}\right)\left(\mathrm{C}_{4} \mathrm{R}_{2}\right)\left(\mathrm{R}=\mathrm{C}_{2^{-}}\right.$ $\left.\mathrm{Bu}^{\mathrm{t}}, \mathrm{Ph} ; \mathrm{R}^{\prime}=\mathrm{Bu}^{\mathrm{t}}, \mathrm{Ph}, \mathrm{SiMe}_{3}\right){ }_{15}^{15}$ which contains a squareplanar metal framework with a highly distorted $\mathrm{C}_{4}$ skeleton.

The degradation of $\mathbf{3}$ and formation of $\mathbf{4}$ is somewhat unexpected but may involve the conversion of the butterfly metal framework to a 64-electron spikedtriangular geometry via addition of $\mathrm{CO}$, followed by removal of the pendant "Ru(CO)" unit as $\mathrm{Ru}_{3}(\mathrm{CO})_{12}$. The assignment of $\mathbf{4}$ foll ows directly from the similarity of spectroscopic data with those of the related, structurally characterized derivatives $\mathrm{Ru}_{3}(\mathrm{CO})_{7}\left(\mu-\mathrm{PPh}_{2}\right)_{2}\left(\mathrm{RC}_{4} \mathrm{R}^{\prime}\right)$ $\left(\mathrm{R}=\mathrm{R}^{\prime}=\mathrm{Ph}\right.$ and $\mathrm{R}=\mathrm{H}, \mathrm{R}^{\prime}=\mathrm{Ph}, \mathrm{Bu}^{\mathrm{t}}$, and $\left.\mathrm{Pr}^{\mathrm{i}}\right) .{ }^{16}$ The dynamic process of the diyne ligand of $\mathbf{4}$, which is similar to the windshield wiper motion of the $\mu_{3}-\eta^{2}$

(14) Mealli, C.; Proserpio, D. M. J . Am. Chem. Soc. 1990, 112, 5484. (15) (a) Bobbie, B.J .; Taylor, N.J .; Carty, A.J . J . Chem. Soc., Chem. Commun. 1991, 1511. (b) Corrigan, J . F.; Doherty, S.; Taylor, N. J .; Carty, A. J . Organometallics 1993, 12, 1365.
Scheme 1

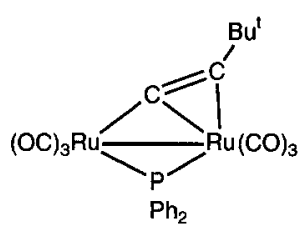

(1)

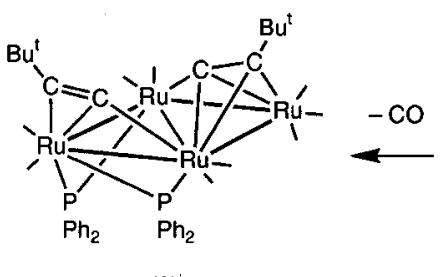

(2)

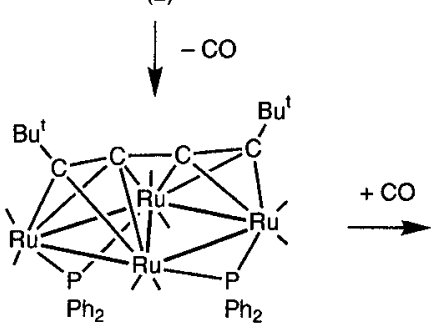

(3)

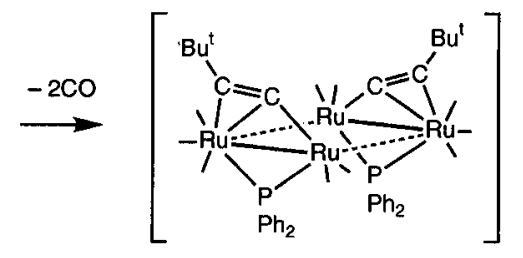

(A)
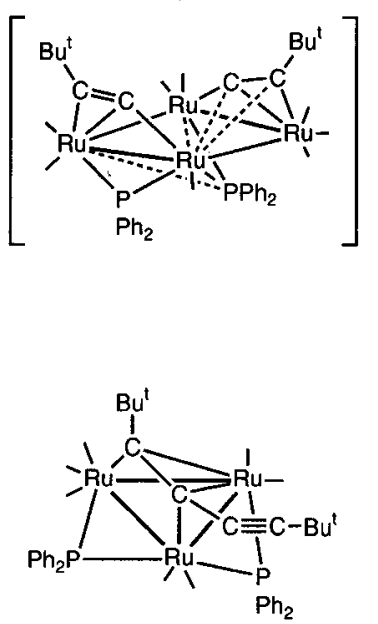

(4) alkynes, ${ }^{17}$ was revealed by the observation of only two doublets at $\delta 275.8$ and 188.3 with a coupling constant ${ }^{2} \mathrm{~J} \mathrm{p-p}$ of $152 \mathrm{~Hz}$ at the limiting temperature of $203 \mathrm{~K}$ and one broad ${ }^{31 P}$ NMR resonance at $\delta 230$ at room temperature.

The high-yield head-to-head intermolecular coupling of $\mu-\eta$-alkynyl groups in converting dinuclear $\mathbf{1}$ to tetranuclear diyne cluster $\mathbf{3}$ may be applicable to the generation of other polyyne ligands on a polymetallic framework from $\mu-\eta^{2}$-butadiynyl or higher polyynyl complexes. ${ }^{18}$ We are currently exploring the synthesis of clusters bearing polyunsaturated $\mathrm{R}(\mathrm{C} \equiv \mathrm{C})_{n} \mathrm{R}$ hydrocarbyls via such reactions.

Acknowledgment. This work was supported by grants from the National Research Council of Canada, the Natural Sciences and Engineering Research Council of Canada (to A.J .C.), and the National Sciences Council of Taiwan (to Y.C. and S.-M.P.; NSC 85-2113-M007008).

Supporting Information Available: Text describing the experimental details for complexes $\mathbf{2}$ and $\mathbf{3}$ and ${ }^{13} \mathrm{C}$ NMR data for $\mathbf{2}$ and full details of crystal structure analyses, including tables of bond distances, atomic coordinates, and anisotropic thermal parameters (14 pages). Ordering information is given on any current masthead page.

\section{OM960507B}

(16) (a) Van Gastel, F.; MacLaughlin, S. A.; Lynch, M.; Carty, A.J .; Sappa, E.; Tiripicchio, A.; Tiripicchio Camellini, M. J . Organomet. Chem. 1987, 326, C65. (b) Corrigan, J . F.; Dinardo, M.; Doherty, S.; Carty, A. J.J . Cluster Sci. 1992, 3, 313.

(17) (a) Busetto, L.; Green, M.; Hesser, B.; Howard, J . A. K.; J effery, J . C.; Stone, F. G. A. J . Chem. Soc., Dalton Trans. 1983, 519. (b) Shapley, J. R.; Park, J . T.; Churchill, M. R.; Bueno, C.; Wasserman, H. J.J . Am. Chem. Soc. 1981, 103, 7385.

(18) Blenkiron, P.; Pilette, D.; Corrigan, J . F.; Taylor, N.J .; Carty, A. J. J . Chem. Soc., Chem. Commun. 1995, 2165. 